\title{
Influence of Crop Age on Nutritional Quality and Hydrogen Cyanide Levels of Roots from Popular Coastal Kenyan Cassava Varieties
}

\author{
Christine Kasichana Katama Masha ${ }^{1}$ Michael Wandayi Okoth ${ }^{2}$ George Ooko Abong ${ }^{2}$ \\ Solomon I. Shibairo ${ }^{3}$ \\ 1.Kenya Agricultural and Livestock Research Organization (KALRO), P.O. Box 4 - 80406Matuga, Kenya \\ 2.Department of Food Science, Nutrition and Technology, University of Nairobi P.O. Box 29053 - 00625 , \\ Nairobi, Kenya \\ 3. Kibabii University, P.O. Box 1699-50200 Bungoma, Kenya
}

The research activities were funded by National Commission for Science, Technology and Innovation (NACOSTI) 2015/2016 FY, laboratory reagents were funded by East African Agricultural Productivity Project (EAAPP)

\section{Abstract}

Cassava is an important crop in coastal Kenya commonly harvested at 12 months after planting but earlier during food shortages. There is limited information that addresses the effect of early harvesting on root quality especially for newly released varieties. Varieties Tajirika, Karembo and Kibanda Meno (roots) were harvested at different ages from Research Centres, studied for nutritional quality and hydrogen cyanide levels for safe utilization. Results showed significant $(\mathrm{p} \leq 0.05)$ interaction effect of varieties and crop age on studied nutrients. Karembo and Tajirika had peak dry matter of $43.42 \%$ and $41.42 \%$ respectively at 12 months while the peak for Kibanda Meno was $44.99 \%$ at 9 months. Mean starch content varied with variety; Karembo (91.3\%), Kibanda Meno (93.4\%), and Tajirika (85.5\%). Karembo and Tajirika had peak carbohydrates at 12 months while the peak for Kibanda Meno was at 9 months. Vitamin C was highest at 6 months for Karembo (6.4 mg/100g) and Kibanda Meno (66 mg/100g). Tajirika had highest vitamin C (7.0 mg/100g) at 9 months. Iron was peak at 3 months for Karembo $(3.63 \mathrm{mg} / 100 \mathrm{~g})$ and Tajirika $(5.33 \mathrm{mg} / 100 \mathrm{~g})$ but at 9 months for Kibanda Meno $(7.12 \mathrm{mg} / 100 \mathrm{~g})$. Peak Zinc was $2.1 \mathrm{mg} / 100 \mathrm{~g}$ for Karembo at 6 months while for Kibanda Meno $(1.94 \mathrm{mg} / 100 \mathrm{~g})$ and Tajirika $(1.75 \mathrm{mg} / 100 \mathrm{~g})$ at 12 months. Hydrogen cyanide increased from 8.6 to $9.3 \mathrm{mg} / \mathrm{kg}$ in Karembo between 9 and 12 months, it decreased from 7.8 to $5.2 \mathrm{mg} / \mathrm{kg}$ and from 5.1 to $4.5 \mathrm{mg} / \mathrm{kg}$ in Tajirika and Kibanda Meno, respectively. Harvesting of cassava roots should be staggered across crop ages to maximize on peaks of different root nutrients and processing is important. Keywords: Cassava varieties, roots, nutrients, hydrogen cyanide, months after planting

DOI: $10.7176 /$ FSQM/88-04

Publication date:July $31^{\text {st }} 2019$

\section{Introduction}

Cassava remains an important food crop in the coastal region of Kenya, ranked second after maize FAOSTAT, (2013). The crop has successfully been incorporated into many farming systems FAO, (2005); FAO, (2005). This has made cassava to be very popular among smallholder farmers. It is one of the traditional crops, and it is significant in coastal dishes and menus Githunguri, (1995). The coast region experiences unfavorable temperatures and rainfall but cassava thrives in sub optimal conditions. This makes it the only food crop of hope to farmers. It therefore has the potential to provide food to rural households during harsh weather conditions when other food crops have failed Imungi et al. (1989).

In 2008, the Kenya Agricultural Research Institute released eight improved cassava varieties for production and consequent utilization by farmers in coastal Kenya KARI, (2009). These varieties were bred for high yield, pest and disease resistance. Post-harvest issues were hardly considered. This is however a common phenomenon where breeders give more emphasis on agronomic traits for targeted varieties with limited studies on postharvest taken in to consideration Bechoff et al. (2018). This created information gaps that need to be addressed. For example, the new varieties still need to be studied to determine their nutrient build up trends- a recommendation documented by Gethi et al. (2009).

Cassava roots are recommended to be harvested at 12 months after planting Muli et al. (2008); Nhassico, (2008) but this only applies under ideal food security situations. Under food shortage, farmers start harvesting cassava as early as three or six months after planting when they notice cracks on the ground FAO, (2005).

Cassava breeders focus on agronomic traits Bechoff et al. (2018) that include disease and pest resistance and improvement of yields in selected varieties KARI, (2009) report proves the same as the newly released varieties were reported to have been evaluated in the national performance trial on basis of the three parameters mentioned above - (pest and disease resistance and yield). Scientific attention is mostly drawn towards dry matter hence limited research has been conducted to evaluate the quality of cassava roots harvested earlier than recommended, especially for the newly released varieties. The parameter that has been studied most in research on cassava root 
quality is dry matter content, whereas the roots also have other components that include carbohydrates, fiber, and ash among others as reported by Motagnac, (2009).

Cassava roots also contain micronutrients that can be exploited to improve nutrient security for the cassava growing and/or consuming communities. In recent years, consumers and food processors have shown considerable interest in foods' nutritional quality, Shobha et al. (2012). Exploitation of micronutrients especially in cassava roots can only be fully achieved if studies are carried out to determine their levels as well as identify the crop age at which they are at peak.

It is important to note that cassava is also known to contain hydrogen cyanide that is poisonous to both humans and livestock, Bechoff et al. (2018). There is still limited information on this compound concerning its concentration in cassava roots at various stages of growth specifically for newly released KARI varieties. Hydrogen cyanide is the bound form of glucoside produced by linamarine that is toxic to both human and animals Cardoso et al. (2005). Determination of hydrogen cyanide levels will enhance consumers' safety especially the consumers of the cassava varieties grown in coastal Kenya. Consumption of unsafe levels of hydrogen cyanide for prolonged periods has been associated with the Konzo disease which mainly affects children Topor et al. (2008). This study sought to evaluate cassava root dry matter, carbohydrate, energy, starch, fiber, ash, protein, fat, hydrogen cyanide and selected micronutrients contents in relation to crop age.

\section{Materials and methods}

\subsection{Acquisition of raw materials}

Three cassava varieties that are popular in the coastal region of Kenya were used for harvesting the experimental materials for this study. These three varieties were; Tajirika, Kibanda Meno and Karembo. Kibanda Meno is an indigenous variety that registers early maturity, high dry matter and sweetness that has led consumers to enjoy it when eating it raw, roasted or boiled Mwamachi, (2005). Kibanda Meno is also known to me more resilient in drought resistance. It is the local variety that is commonly grown alongside the improved varieties as means of risk mitigation over crop loss Wekesa et al. (2017). Though Kibanda Meno has low yield (2.02 t/acre) and susceptible to diseases as reported by Gethi et al. (2009), the coastal communities have remained persistent on their preference to grow Kibandameno Mwamachi, (2005). Karembo and Tajirika are improved varieties that were bred and released by KARI in the year 2008. These varieties were bred for pest and disease resistance and also high yields. Karembo has a yield potential of up to 27 tons per hectare and Tajirika has yield potential of up to 25 tons per hectare Muli et al. (2009). Variety Karembo has a stem that is characterized by short internodes (Muli et al. 2009) and producers have adopted it for seed multiplication, a part from the high yields. Variety Tajirika has most of its traits almost similar to those found in the local variety Kibanda Meno, apart from dry matter content that is said to be lower. Tajirika however has long roots with medium thickness that make them preferred in the fresh market Muli et al. (2009).

The varieties: were obtained from mother blocks at three Kenya Agricultural and Livestock Research Organization (KALRO) Centres. The three Centers were; Masabaha, Matuga and Mtwapa .A total of 4 healthy plants were randomly selected and harvested at 3, 6, 9 and 12 months after planting. Harvesting of roots was carried out using a hoe. The hoe was used to carefully remove top soil in order to dig out the roots while ensuring minimal bruises. A total of 3 medium sized roots were harvested from each plant. The roots were then packaged in labeled polyethylene bags per variety and per age group. The labelled roots were then put in cooler boxes for overnight transportation to the University of Nairobi for analysis in the Food Science Laboratories. The roots were prepared by washing before and after peeling, and macerating using laboratory blender. Macerated root mashes were well mixed accordingly and sampled in replicates for analysis.

\section{1. 1 Determination of Moisture /Dry Matter (DM) content}

Moisture content determination was carried out using gravimetric method with a few modifications. About $5 \mathrm{~g}$ of macerated sample were weighed in crucibles and dried for 4 hours at $105^{\circ} \mathrm{C}$ in an air oven as described by AOAC, (2001) method 925.10.

\section{1. 2 Determination of Starch Content}

Cassava starch content was determined by standard methods AOAC, (2012) method 985.29, with minimal modification where filtration of roots' mash to remove starch was done using a cheese cloth instead of a sieve with known mesh size. Before filtration, root mash had been mixed with distilled water at ratio of 2:1.

\section{1. 3 Determination of Energy Content}

The energy content was obtained by multiplying the value of crude protein, fat and carbohydrate by factors of 4 , 9 and 4 respectively as indicated by Omosuli, (2014).

\section{1. 4 Determination of Crude Fiber}

Crude fiber was determined as described by AOAC, (2000) method 985.29. A duplicate $4 \mathrm{~g}$ sample of root mash was boiled for 30 minutes in $25 \mathrm{ml}$ of $2.04 \mathrm{~N} \mathrm{H}_{2} \mathrm{SO}_{4}$ diluted to $200 \mathrm{ml}$ with boiling distilled water. The mixture was then filtered by use of a buchner funnel slightly packed with glass wool. The collected residue was washed thrice with ethanol, followed with air oven drying at $105^{\circ} \mathrm{C}$ for 2 hours then ashed at $550^{\circ} \mathrm{C}$ in a muffle furnace. 


\section{1. 5 Determination of Ash Content}

Briefly $4 \mathrm{~g}$ sample of cassava root mash in duplicate was burnt in porcelain crucible using Bunsen burner (low flame) for 10 minutes then transferred to a Muffle furnace, ashed at $550^{\circ} \mathrm{C}$ for 4 hours as guided in AOAC, (1995) method 923.03

\section{1. 6 Determination of Crude Fat}

Briefly $5 \mathrm{~g}$ sample was extracted using soxhlet extractor for 8 hours using $200 \mathrm{ml}$ petroleum ether $\left(40-60^{\circ} \mathrm{C}\right)$. Crude fat content was calculated after evaporating the solvent and the residue dried in an air oven at $105^{\circ} \mathrm{C}$ for 1 hour as guided by Mishra, (2017).

\section{1. 7 Determination of Protein}

Protein content in cassava roots was determined as per AOAC, (2005) method 979.09.

\section{1. 8 Determination of Hydrogen Cyanide}

Hydrogen cyanide determination was carried out using distillation method. Cassava roots were macerated using a laboratory blender and samples of $10 \mathrm{~g}$ root mash was placed into distillation flask and allowed to stand for three hours before distillation. Distillation and consequent determination of hydrogen cyanide was carried out as guided in AOAC, (2016) method 915.03.

\section{1. 9 Determination of Carbohydrates}

Carbohydrates were determined by difference. The total of moisture content, fat, ash, protein and fibre contents were subtracted from 100 as guided in FAO, (2003)

\section{2. Determination of Vitamin C}

Approximately $15 \mathrm{ml}(10 \%) \mathrm{TCA}$, was added into flat bottomed flask containing cassava roots mash and filtered. A total of $15 \mathrm{ml}$ filtrate sample was collected. The filtrate sample was then mixed with $5 \mathrm{ml}$ of $4 \%$ potassium iodide solution then titrated. The rest of procedure was followed as described in AOAC (2013) method 967.21.

\section{2. 1 Determination of Iron and Zinc Content}

Cassava root mash sample $(4 \mathrm{~g})$ for determining mineral Iron was ashed in a muffle furnace at $500{ }^{\circ} \mathrm{C}$ for 4 hours. Then digested by adding $10 \mathrm{mls}$ of $20 \% \mathrm{HCL}$ to boiling, then filtered into $100 \mathrm{ml}$ volumetric flask and topped to mark using distilled water. Using atomic absorption spectrophotometer (A.A.S) mineral iron and zinc was determined according to AOAC, (2016) method 99. 10

\section{2. 2 Experimental Design and Data Analysis}

The statistical design used in the study was Complete Randomized Design, where varieties and crop growth stage were independent variables. Data were collected on the following parameters: Hydrogen cyanide levels, Carbohydrates in, Starch, Fiber and Dry matter, protein, fat and selected micronutrients. Results from laboratory analyses were subjected to the analysis of variance (ANOVA), using Statistical Analysis System (SAS version 9.1). Means were separated using Least Significant Difference (LSD), the differences being significant when $\mathrm{p} \leq 0.05$.

3. Results and discussion

3. 1 Dry matter and starch content

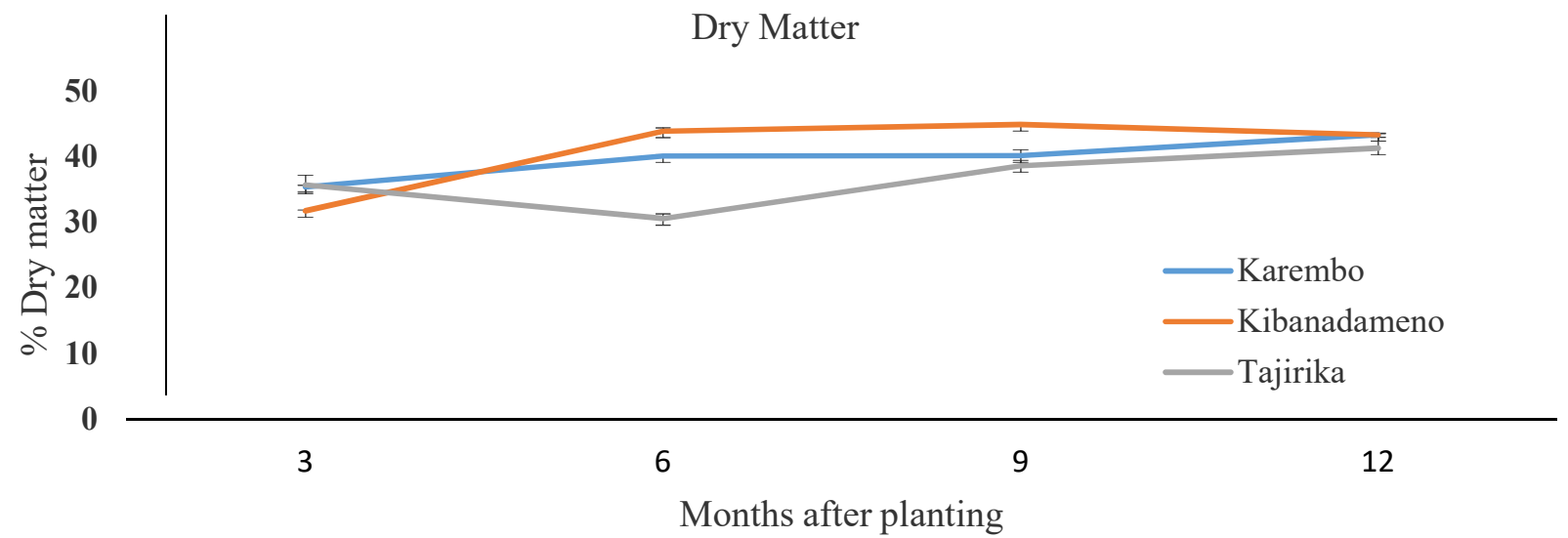

Figure 1: Dry matter content (\%) of cassava roots as affected by crop age. The bars indicate standard error bars.

There was significant $(\mathrm{p} \leq 0.05)$ interaction between variety and crop age on dry matter, starch, carbohydrate, energy, fiber, ash and hydrogen cyanide Kibanda Meno contents. While varieties Karembo and Tajirika attained the highest root dry matter content ( $43.42 \%$ and $41.42 \%$ respectively) at 12 months after planting, the local variety Kibanda Meno attained the highest dry matter content (44.99\%), 9 months after planting (Figure 1). 
There was no significant difference $(\mathrm{p}>0.05)$ in dry matter content for Karembo and Kibanda Meno harvested at either 6 or 9 months after planting. Tajirika harvested at 9 months after planting had 38.7\% dry matter content as compared with $30.6 \%$ at 6 months. Between 9 and 12 months after planting, Karembo and Tajirika had accumulated $8.0 \%$ and $7 \%$ higher dry matter content, respectively. The dry matter content of Kibanda Meno dropped by $8 \%$ when left in the field beyond 9 months and harvested at 12 months after planting. These results indicate that farmers who use root dry matter content as the criterion for choice of cassava variety will still prefer the local variety, Kibanda Meno, since they would be able to harvest it as early as six months after planting. However, the improved varieties Karembo and Tajirika give yields of up to 27 and $25 \mathrm{t} / \mathrm{ha}^{-1}$ respectively compared to Kibanda Meno that gives 5 to $10 \mathrm{t} / \mathrm{ha}^{-1}$ under similar conditions and cultural treatment. Therefore, farmers who adopt the improved varieties will be better off, even though they will have to wait a little longer to start harvesting their cassava. Dry matter content of the coastal varieties is higher compared to those reported by Montagnac, (2009) and Benesi, (2004) that ranged between $35 \%$ and $38 \%$. It is important to note that dry matter in cassava plays a major role for a variety to be accepted for both consumption and production Bechoff et al. (2018). Dry matter is also the indicator component for higher starch and carbohydrates content that are sought for to supply the daily energy requirements for the cassava growing households and the cassava growing communities. The results in this study showed a 13\% drop in dry matter at 6 months after planting of variety Tajirika. Agronomists have linked such scenario with growth pattern, especially when the crop is at its maiden stage of attaining crucial biomass to support its growth and or flowers. It is well demonstrated when cassava is cut back to allow for a ratoon crop, dry matter drops to non-palatable state as the new biomass establishes. Gethi, (2009) reported higher biomass at 6 months after planting of the improved varieties. However, this remains an information gap that could be established through research.

\section{Starch Content}

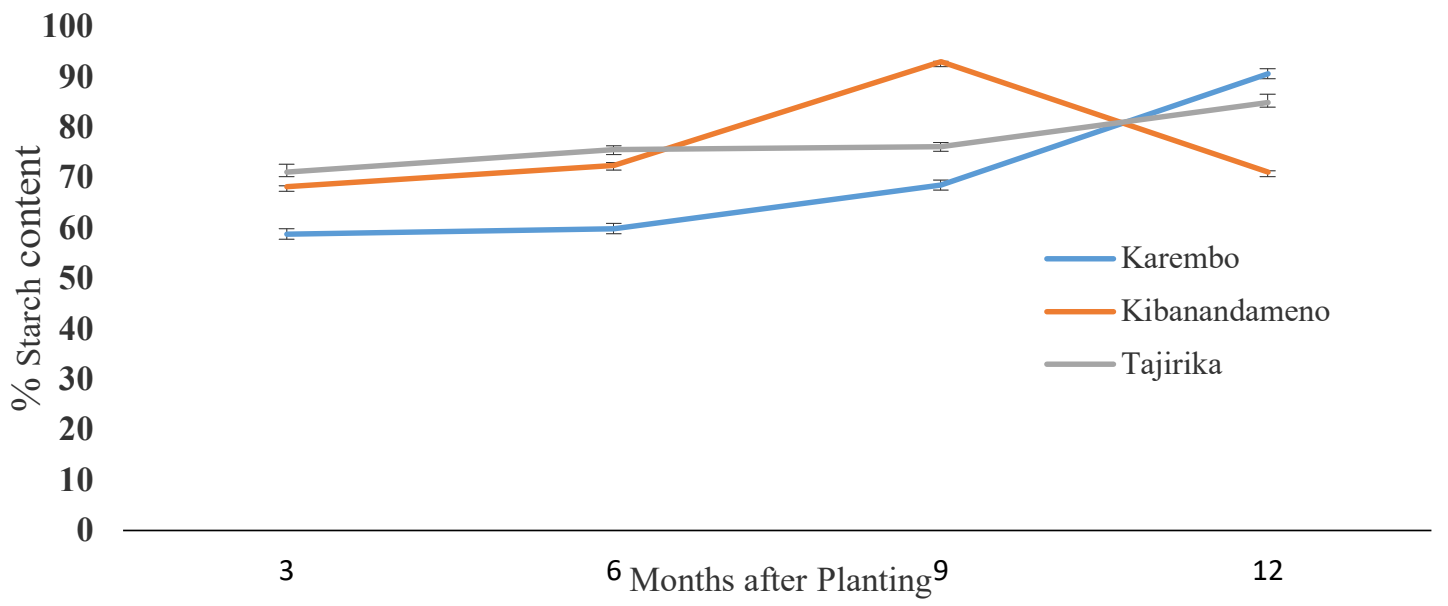

Figure 2: Variation of Starch content (\% dry weight basis (dwb)) of cassava roots as affected by crop age. The bars indicate standard error of means.

There was significant $(\mathrm{p} \leq 0.05)$ effect of crop age on starch content in Kibanda Meno. The starch content of Kibanda Meno increased from $68.2 \%$ to $93 \%$ (on dry weight basis (dwb)) between 3 and 9 months after planting (Figure 2). Starch content in variety Kibanda Meno reduced by 3.3\% when harvested at 12 months instead of 9 months after planting. On a dry weight basis (dwb), the results showed that the three varieties evaluated in this study had starch content ranging from $68.5 \%$ to $93 \%$ at 9 months after planting. These results compared well with those reported by Mouafi et al. (2018) Varieties studied by Montagnac Montagnac et al. (2009) had starch content that correspond well with the results in the current study though they were reported on wet basis. Montagnac's varieties had starch content range of 32-35\% - reported on wet weight basis.

Kibanda Meno had the highest starch content of 93\% (dwb) compared to Karembo and Tajirika that had 76\% and $69 \%(\mathrm{dwb})$ respectively when harvested at 9 months after planting. This scenario could be due to varieties' genetic characteristics and also as influenced by other factors including climatic conditions as postulated by Salvador Salvador et al. (2014); Bechoff et al. (2018); Burns et al. (2012). These values are relatively high in comparison to those reported by Eke et al. (2007) where 39 cassava varieties showed percent starch content that ranged between $20.2 \%$ and $31.8 \%$. Inasmuch as the coastal region is known for poor soil fertility and harsh climatic conditions the varieties are competing well in starch build up with varieties grown under favourable conditions elsewhere. The trend in the current study also shows a consistent accumulation of starch content in roots through to 12 months after planting. 


\section{1. 2 Proximate composition}

There was significant $(\mathrm{p} \leq 0.05)$ difference in carbohydrate content accumulation for the improved varieties and Kibandameno - the local variety. The improved varieties had peak accumulation of carbohydrates at 12 months while Kibanda Meno had its peak at 9 months after planting. Crop age 6 to 9 months had significant $(\mathrm{p} \leq 0.05)$ effect on carbohydrate content of Kibanda Meno and Tajirika. Tajirika had the highest increase in this age range at $31.8 \%$. The carbohydrate content of Karembo was $37.6 \%$ at 9 months and $40.5 \%$ (dwd) at 12 months after planting (Table 1). These results are within the range of carbohydrates contents that was reported by Richardson, (2013) who tested six mature improved varieties harvested at between 12 and 13 months after planting. The six varieties evaluated by Richardson, (2013) had carbohydrates content of between $26.3 \%$ and $39.6 \%$ (dwb). However, the nutritional content of cassava depends on geographic location, variety, age of the plant and the specific plant part (root or leaves) and environmental conditions Salvador et al. (2014); Bechoff et al. (2018); Burns et al. (2012)

Crop age had significant $(\mathrm{p}<0.05)$ effect that resulted to change in energy content of cassava roots between 3 and 12 months after planting. There was $17.9 \%, 41.3 \%$ and $40.1 \%$ increase in energy (kcal/100 g dry weight) content, for Karembo, Kibanda Meno and Tajirika, respectively during this period. Variety Karembo had 11\% increase in energy content from 3 to 6 months after planting while Kibanda Meno and Tajirika had 38\% and 17.1\% increase respectively over the same period. Energy content in Kibanda Meno increased by $3 \%$ while energy content in Tajirika roots increased by 7\% between 6 months after planting and $9-12$ months after planting, while variety Karembo added $9.4 \%$ energy content over the same period of time. These results show that energy content of coastal varieties is averagely higher compared to those varieties reported by Montagnac, (2009). At 12 months after planting energy contents of the coastal varieties were as follows: Karembo had $169.8 \mathrm{kcal} / 100 \mathrm{~g}$ dry weight, Kibanda Meno had $155.7 \mathrm{kcal} / 100 \mathrm{~g}$ dry weight and Tajirika had $161.2 \mathrm{kcal} / 100 \mathrm{~g}$ wet weight. The varieties tested by Montagnac had energy content of between 110 and $149 \mathrm{kcal}$ per $100 \mathrm{~g}$ dry weight. This is a positive indicator that popularizing cassava varieties in the coast region can help households acquire a bigger percentage of the daily required calories. This makes them more suitable for processing whole root product.

The change in fibre content for Tajirika was not statistically significant ( $p>0.05)$. At 6 months after planting, the fibre content of Karembo, Kibanda Meno and Tajirika increased by 53.5\%, 41\% and 49\% respectively (Table 1). However, there was a decline in fiber content by $18 \%, 17 \%$ and $31 \%$ between 6 and 9 months for Karembo, Kibanda Meno, and Tajirika, respectively. The fiber content of Kibanda Meno increased by 30\% between 9 and 12 months after planting. Tajirika had its fiber content decrease by $9 \%$ as it matured between 9 and 12 months after planting. The results indicate that the improved varieties (Karembo and Tajirika) become less fibrous when left longer in the field to be harvested at 12 months but Kibanda Meno accumulates more fiber when left to reach 12 months after planting. The fibre content in the coastal cassava varieties is rather low at $0.9 \%$ to $1.3 \%$ (dwd) across the 3 varieties, as compared to results reported by Enidiok et al. (2008) who tested 7 cassava varieties from Ethopian Agricultural Centre and found that fibre content in all of them ranged between 1.7\% and 1.8\%. However, Aileyegun et al. (2017) reported fiber content in cassava ranging between 0.48 and $2.59 \%$ (dwb) in their studies on gari. The less fibrous cassava roots are the more palatable and well accepted by producers, consumers and processors Burns et al. (2012); Bechoff et al. (2018), the coastal varieties therefore would compete well with other varieties at farm gate, fresh or processing markets.

Ash content in the three varieties was between 0.67 to 0.98 in variety Karembo, 0.84 to 1.29 in variety Kibanda Meno and 0.65 to 1.03 in variety Tajirika. (Table 1$)$ The results showed significant $(\mathrm{p} \leq 0.05)$ interaction between crop age and ash content. The change in ash content between 3 and 6 months after planting for variety Karembo was a $23.4 \%$ decline but crop age 6 to 9 months after planting showed a $2.7 \%$ increase in ash content. This is an indicator that variety Karembo's roots left in the field beyond 9 months after planting does not guarantee increase of nutrients. Variety Kibanda Meno had a significant $(\mathrm{p} \leq 0.05)$ change that was characterized with consistent increase in ash content of up $53.4 \%$, from 3 to 12 months. Variety Tajirika showed a similar trend with Karembo where there was a significant $(\mathrm{p} \leq 0.05)$ decline of $36.9 \%$ from 3 to 6 months after planting followed by $18.5 \%$ increase in ash content from 6 to 9 months after planting. From 9 to 12 months after planting Tajirika, however, showed $27.3 \%$ increased ash content (Table 1). However, the change in ash content for Tajirika was not statistically significant $(\mathrm{p}>0.05)$. An increase in age from 3 to 6 months decreased the ash content by $23.5 \%$ and $36.9 \%$ in the roots of Karembo and Tajirika, respectively, while the same increase in age increased the root ash content of Kibanda Meno by $12 \%$. Variety Kibanda Meno had the highest ash content in comparison with the improved varieties. The results on improved varieties are high compared to those reported by Kalawole and Akigbala, (2010) where ash content was $0.54 \%(\mathrm{dwb})$ in roots harvested at 12 months and above after planting. However, Montagnac, (2009) reported ash content of 0.4 to $1.7 \%$ (dwb) from roots of assorted cassava varieties. 
Table 1: Means of Proximate nutrients contents $(\% \mathbf{d w b})$ of three coastal cassava varieties as affected by crop age

\begin{tabular}{llcccc}
\hline $\begin{array}{l}\text { Cassava root } \\
\text { Nutrients }\end{array}$ & $\begin{array}{l}\text { Cassava } \\
\text { Variety }\end{array}$ & $\begin{array}{c}\text { 3 Months } \\
\text { after planting }\end{array}$ & $\begin{array}{c}\text { 6 Months } \\
\text { after planting }\end{array}$ & $\begin{array}{c}\text { 9 Months after } \\
\text { planting }\end{array}$ & $\begin{array}{c}\text { 12 Months } \\
\text { after planting }\end{array}$ \\
\hline Carbohydrates \% & Karembo & $39.00 \pm 0.01^{\mathrm{c}}$ & $37.28 \pm 0.28^{\mathrm{de}}$ & $37.58 \pm 0.37^{\mathrm{d}}$ & $40.48 \pm 0.26^{\mathrm{ab}}$ \\
& Kibandameno & $30.01 \pm 0.01^{\mathrm{h}}$ & $39.86 \pm 0.2^{\mathrm{b}}$ & $40.81 \pm 0.24^{\mathrm{a}}$ & $37.12 \pm 0.16^{\mathrm{de}}$ \\
Energy (kcal/100g & Tajirika & $35.84 \pm 0.17^{\mathrm{f}}$ & $26.65 \pm 0.06^{\mathrm{i}}$ & $35.15 \pm 0.14^{\mathrm{g}}$ & $36.86 \pm 0.69^{\mathrm{e}}$ \\
& Karembo & $139.49 \pm 0.63^{\mathrm{f}}$ & $155.0 \pm 0.15^{\mathrm{d}}$ & $155.15 \pm 1.40^{\mathrm{d}}$ & $169.81 \pm 0.74^{\mathrm{ab}}$ \\
& Kibandameno & $122.81 \pm 4.04$ & $169.04 \pm 1.77$ & $173.52 \pm 0.10^{\mathrm{a}}$ & $155.65 \pm 0.68^{\mathrm{d}}$ \\
& & $\mathrm{h}$ & $\mathrm{b}$ & & \\
& Tajirika & $134.79 \pm 0.63$ & $115.12 \pm 0.77$ & $150.69 \pm 1.08^{\mathrm{e}}$ & $161.23 \pm 3.72^{\mathrm{c}}$ \\
& & $\mathrm{g}$ & $\mathrm{i}$ & & \\
& Karembo & $0.71 \pm 0.00^{\mathrm{i}}$ & $1.08 \pm 0.03^{\mathrm{d}}$ & $0.93 \pm 0.01^{\mathrm{g}}$ & $0.92 \pm 0.01^{\mathrm{g}}$ \\
& Kibandameno & $0.83 \pm 0.01^{\mathrm{h}}$ & $1.17 \pm 0.01^{\mathrm{c}}$ & $1.03 \pm 0.01^{\text {ef }}$ & $1.29 \pm 0.01^{\mathrm{b}}$ \\
& Tajirika & $1.04 \pm 0.01^{\mathrm{f}}$ & $1.55 \pm 0.06^{\mathrm{a}}$ & $1.06 \pm 0.01^{\mathrm{e}}$ & $1.01 \pm 0.01^{\mathrm{f}}$ \\
& Karembo & $0.98 \pm 0.02^{\mathrm{b}}$ & $0.75 \pm 0.07^{\mathrm{e}}$ & $0.77 \pm 0.04^{\mathrm{d}}$ & $0.67 \pm 0.02^{\mathrm{f}}$ \\
& Kibandameno & $0.84 \pm 0.01^{\mathrm{d}}$ & $0.94 \pm 0.02^{\mathrm{c}}$ & $0.96 \pm 0.01^{\mathrm{bc}}$ & $1.29 \pm 0.01^{\mathrm{a}}$ \\
& Tajirika & $1.03 \pm 0.01^{\mathrm{b}}$ & $0.65 \pm 0.00^{\mathrm{g}}$ & $0.77 \pm 0.06^{\mathrm{d}}$ & $0.98 \pm 0.04^{\mathrm{b}}$ \\
\hline
\end{tabular}

Means followed with the same superscript in the same row are not significantly different at $5 \%$ level of significance

Fat content was shown to be low ranging between 0.2 and $0.8 \%$ dwb (Table 2). The results of the current study showed significant $(\mathrm{p} \leq 0.05)$ interaction effect on cassava roots fat content. The variation on the coastal varieties is wider compared to 6 varieties studied by Richardson (2013), whose range of variation was between 0.2 and $0.4 \%(\mathrm{dwb})$ fat content. The results conform to those reported by Ifeabunike, et. al. (2017) who reported fat content of $0.78 \%$ for the bitter varieties and $0.27 \%$ for sweet varieties.

Change in protein content for variety Karembo, from 3 to 6 months after planting was $74.7 \%$ decrease, $4.5 \%$ decrease from 6 to 9 , however protein content increased from $0.21 \%$ to $0.50 \%$ (dwb) from 9 to 12 months after planting (Table 2), this culminates to $138 \%$ increase. Variety Kibanda Meno showed a decrease of $37.8 \%$ from 3 to 6 months after planting, 7.14\% increase from 6 to 9 months after planting and a decrease of protein content of $3.33 \%$ from 9 to 12 months after planting.

Variety Tajirika showed a decrease of $42 \%$ from 3 to 6 months after planting, then an increase of $117.24 \%$ from 6 to 9 months after planting. Another increase of 22.2\% protein content was shown from 9 to 12 months after planting. These results indicate a significant $(\mathrm{p}<0.05)$ interaction effect of crop age and variety on protein content. Karembo had the highest protein content at 3 months after planting followed by Tajirika whose highest protein content was at 12 months after planting. Variety Kibanda Meno had its peak protein at month 6 while Karembo's peak was at month 3. This conforms to the study carried out by Richardson and Benesi where six varieties evaluated for quality showed a range of 1.20 to $2.10 \%$ protein at 12 and 13 months after planting Richardson, (2013); Benesi, et al. (2004). Chavez also observed that protein content is quite low in cassava roots Chavez et al. (2005), with Salcedo showing that protein content in cassava roots ranging between 1\% and 3\% Salcedo et al. (2010) . This shows that the popular varieties grown in coastal Kenya have lower protein content than other varieties elsewhere. It is advisable therefore that consumers supplement cassava roots dishes with protein source. Also in order to maximize on the little protein contained in cassava roots Tajirika has peak protein levels at 12 months, Kibanda Meno at 6 months and Karembo at three months after planting therefore it is advisable that harvesting of roots to be staggered accordingly

The change in root hydrogen cyanide content between 3 and 12 months after planting was $0.12 \%$ to $9.34 \%$, $0.12 \%$ to $5.24 \%$ and $0.13 \%$ to $4.47 \%$ for Karembo, Kibanda Meno and Tajirika respectively (Table 2). While longer period in the field from 6 to 9 months after planting had no effect on root hydrogen cyanide content in Karembo, Kibandameno and Tajirika accumulation was $22 \%$ and $37 \%$ times more cyanide over the same period of time. Longer period in the field from 9 to 12 months showed accumulation of hydrogen cyanide content in the roots of Karembo by $8 \%$, while the same period caused $33 \%$ and $12 \%$, reduction of hydrogen cyanide content in the roots of Kibanda Meno and Tajirika by respectively. Results in this study show that the coastal varieties had hydrogen cyanide content that range between $0.12 \mathrm{mg} / \mathrm{kg}$ to $13.00 \mathrm{mg} / \mathrm{kg}$ dry weight. The results are higher compared to results reported by Onwuka and Ogbogu, (2007) whose two varieties (one improved and a local) had hydrogen cyanide levels of $3.1 \mathrm{mg} / \mathrm{kg}$ and $3.6 \mathrm{mg} / \mathrm{kg}$ respectively in roots harvested at full maturity, i.e. over 12 months after planting. The results are, however, comparing well with those reported by Ubwa et al. (2015). The accepted hydrogen cyanide levels by codex standards Codex, (1989) is up to $10 \mathrm{mg} / \mathrm{Kg}$ that is equivalent to $10 \mathrm{ppm}$ Endmemo, (2017) On the other hand hydrogen cyanide levels that were reported to be endemic with reference to Konzo disease, were between 47 and $614 \mathrm{mg} / \mathrm{kg}$ Rijssen et al. (2013); Bolhuis, (1966) as cited in Lukuyu et al. (2014) observed that Hydrogen cyanide content that is below $50 \mathrm{mg} / \mathrm{kg}$ is innocuous. The coastal varieties have 
hydrogen cyanide range of between $9.3 \mathrm{mg} / \mathrm{kg}$ and $12 \mathrm{mg} / \mathrm{kg}$ - conversion done using Endmemo (2017) convertor table. Variety Karembo however has high cyanide content across the studied crop ages. Studies by Topor et al. (2008) showed storage of fresh roots caused hydrogen cyanide levels to decline. However moisture stress on cassava roots in the field causes hydrogen cyanide level to rise- as reported by Srihawong et al. (2015). The trend shown in this study on hydrogen cyanide build up indicate a moisture stress on the roots as hydrogen cyanide was shown to rise as the roots were left longer in the field. Moisture stress is a common phenomenon in the coastal region of Kenya.

Table 2: Proximate composition (dwb) of three coastal Kenya cassava varieties as affected by crop age

\begin{tabular}{llllll}
\hline $\begin{array}{c}\text { Cassava root } \\
\text { nutrients }\end{array}$ & \multicolumn{1}{c}{$\begin{array}{c}\text { Cassava } \\
\text { varieties }\end{array}$} & $\begin{array}{c}\text { 3 months after } \\
\text { planting }\end{array}$ & $\begin{array}{c}6 \text { months after } \\
\text { planting }\end{array}$ & $\begin{array}{c}9 \text { months after } \\
\text { planting }\end{array}$ & $\begin{array}{c}12 \text { months } \\
\text { after planting }\end{array}$ \\
\hline Fat \% & Karembo & $0.87 \pm 0.4^{\mathrm{a}}$ & $0.22 \pm 0.01^{\mathrm{f}}$ & $0.21 \pm 0.01^{\mathrm{g}}$ & $0.50 \pm 0.06^{\mathrm{d}}$ \\
& Kibandameno & $0.45 \pm 0.02^{\mathrm{d}}$ & $0.28 \pm 0.01^{\mathrm{efg}}$ & $0.30 \pm 0.01^{\mathrm{e}}$ & $0.29 \pm 0.00^{\mathrm{ef}}$ \\
& Tajirika & $0.50 \pm 0.01^{\mathrm{d}}$ & $0.29 \pm 0.08^{\mathrm{f}}$ & $0.63 \pm 0.04^{\mathrm{c}}$ & $0.77 \pm 0.02^{\mathrm{b}}$ \\
Protein $\%$ & Karembo & $1.13 \pm 0.03^{\mathrm{d}}$ & $0.77 \pm 0.01^{\mathrm{fg}}$ & $0.74 \pm 0.06^{\mathrm{h}}$ & $0.88 \pm 0.05^{\text {ef }}$ \\
& Kibandameno & $0.41 \pm 0.01^{\mathrm{h}}$ & $1.54 \pm 0.11^{\mathrm{ab}}$ & $0.94 \pm 0.00^{\mathrm{e}}$ & $1.15 \pm 0.00^{\mathrm{d}}$ \\
& Tajirika & $1.33 \pm 0.08^{\mathrm{c}}$ & $1.49 \pm 0.04^{\mathrm{b}}$ & $1.12 \pm 0.05^{\mathrm{d}}$ & $1.63 \pm 0.06^{\mathrm{a}}$ \\
$\mathrm{HCNmg} / \mathrm{kg}$ & Karembo & $0.12 \pm 0.00^{\mathrm{c}}$ & $8.5 \pm 0.01^{\mathrm{b}}$ & $8.62 \pm 0.76^{\mathrm{b}}$ & $9.34 \pm 0.45^{\mathrm{a}}$ \\
& Kibandameno & $0.12 \pm 0.01^{\mathrm{f}}$ & $2.62 \pm 0.12^{\mathrm{e}}$ & $57.80 \pm 0.38^{\mathrm{c}}$ & $4.47 \pm 0.54^{\mathrm{d}}$ \\
& Tajirika & $13.00 \pm 0.01^{\mathrm{f}}$ & $4.80 \pm 0.30^{\mathrm{d}}$ & $10 \pm 0.01^{\mathrm{d}}$ & $5.24 \pm 0.03^{\mathrm{d}}$ \\
\hline
\end{tabular}

*Means followed with the same superscript in the same row are not significantly different at $5 \%$ level of significance

The results of the current study showed significant $(\mathrm{p} \leq 0.05)$ interaction effect on cassava roots vitamin $\mathrm{C}$ content (Table 3). The three varieties registered vitamin $\mathrm{C}$ content that ranged from $7 \mathrm{mg} / 100 \mathrm{~g}$ to approximately $70 \mathrm{mg} / 100 \mathrm{~g}$ across the 4 crop ages studied. After determining the $\%$ change per variety Karembo showed that the change in vitamin $\mathrm{C}$ content in was up to $585.89 \%$ increase from 3 to 6 months after planting, after which there was a 31\% reduction from 6 to 9 month after planting and then a further $26.79 \%$ reduction from 9 to 12 months after planting Variety Kibandameno had persistent decline in vitamin $\mathrm{C}$ content in the following trend from 3 to 6 months $(796.21 \%), 6$ to 9 months $(7.97 \%)$ and $22.94 \%$ after planting, from 9 to 12 months after planting. Variety Tajirika had a vitamin C content increase of $445.38 \%$ from 3 to 6 months after planting. Then an increase of $23 \%$ from 6 to 9 months after planting and a decrease of $13.76 \%$ from 9 to 12 months after planting. Therefore, varieties Karembo and Kibanda Meno showed a decreasing trend in vitamin $\mathrm{C}$ content when left in the field for a period beyond 6 months after planting, while Tajirika's vitamin $\mathrm{C}$ content started decreasing when left in the field beyond 9 months after planting (Table 3$)$. There was therefore significant $(p \leq 0.05)$ interaction effect between vitamin $\mathrm{C}$ content (mg/100 g dry weight) and crop age.

The results showed substantial high content of vitamin $\mathrm{C}$ in all the three varieties, Karembo $64.2 \mathrm{mg} / 100 \mathrm{~g}$, Kibanda Meno 66 and mg Tajirika $69.6 \mathrm{mg} / 100 \mathrm{~g}$. These results are higher than those reported by Montagnac, (2009) whose results were 14.9 to $50 \mathrm{mg} / 100 \mathrm{~g}$. They however compare well with those reported by Davidson et al. (2017). Salvador et al. (2014) postulates that chemical content of cassava varies depending on the plant part, climatic and environmental condition and agro - ecological location of production. Peak vitamin $\mathrm{C}$ content also significantly varied, Tajirika. Karembo and Kibanda Meno attained their highest vitamin $\mathrm{C}$ content at 6 months after planting. Tajirika had its highest level of vitamin $\mathrm{C}$ at 9 months after planting. The results indicate that cassava roots for Karembo and Kibanda Meno loose vitamin C when left in the field longer than 6 months after planting. The percent drop in vitamin C content from 6 to 9 months after planting was as follows; Karembo $30.9 \%$ and Kibanda Meno $7.9 \%$ when harvested at 9 months after planting instead of harvesting them at 6 months after planting. Tajirika's vitamin C content however drops when the variety is left in the field beyond 9 months after planting (Table 3).

\section{1. 3 Variation in mineral contents}

The change in variety Karembo for mineral iron content was a persistent accumulation from 3 to 6 months after planting $(41.05 \%)$ and $25.23 \%$ from 6 to 9 months after planting. At 9 to 12 months after planting the results showed $12.62 \%$ decline in mineral iron content (Table 3). Variety Kibanda Meno had $28.9 \%$ decline in mineral iron content from 3 to 6 months, then had an increase of $134.98 \%$ from 6 to 9 months after planting, then showed a decrease of $26.97 \%$ from 9 to 12 months. Variety Tajirika showed a decrease of $46.15 \%$ from 3 to 6 months after planting, then another decrease of $17.42 \%$ from 6 to 9 months after planting. There was further decrease of $5.48 \%$ mineral iron content from 9 to 12 months after planting. The results therefore showed significant $(\mathrm{p} \leq 0.05)$ interaction effect on cassava roots in relation to iron content (Table 3$)$. Kibanda Meno had significantly $(p \leq 0.05)$ higher iron content in all the crop ages compared to the improved varieties. At 3 months after planting, Kibanda Meno had $4.3 \mathrm{mg} / 100 \mathrm{~g}$ dry weight iron content that indicated to be higher $14.7 \%$ than Karembo's iron content, that stood at $3.6 \mathrm{mg} / 100 \mathrm{~g}$ dry weight. Peak iron content was found to be at the tender crop age of 3 months after 
planting for the improved varieties. Karembo $(3.6 \mathrm{mg} / 100 \mathrm{~g}$ dry weight) and Tajirika $(5.3 \mathrm{mg} / 100 \mathrm{~g}$ dry weight), while variety Kibanda Meno had its peak iron content $(7.12 \mathrm{mg} / 100 \mathrm{~g}$ dry weight) at 9 months after planting. These results are within the range reported by Ifeabunike et al., (2017) and Davidson et al. (2017), who reported iron content of $2.25 \mathrm{mg} / 100 \mathrm{~g}$ dry weight for bitter varieties and $4.0 \mathrm{mg} / 100 \mathrm{~g}$ dry weight for the sweet varieties. Studies carried out by Chavez et al. (2000) showed a mean iron content of $9.6 \mathrm{mg} / 100 \mathrm{~g}$ dry weight in cassava roots, while Montagnac's results were at $0.3 \mathrm{mg} / 100 \mathrm{~g}$ dry weight to $14.0 \mathrm{mg} / 100 \mathrm{~g}$ dry weight Montagnac, (2009). This is however expected since cassava nutrients and/or physical characteristics are influenced by several factors as stated by Salvador et al. 2014).

Change in mineral zinc content showed of $176.32 \%$ accumulation in variety Karembo when left in the field from 3 to 6 months after planting, then there was a $60 \%$ reduction when the crop was left in the field from 6 to 9 months after planting, and a further $73.81 \%$ accumulation of mineral zinc from 9 to 12 months after planting. Variety Kibanda Meno showed $54.72 \%$ increase in mineral zinc content from 3 to 6 month after planting. There was $18.28 \%$ reduction of mineral zinc from 6 to 9 months after planting. There was $190 \%$ accumulation of mineral zinc content from 9 to 12 months after planting. Variety Tajirika showed $96.83 \%$ change from 3 to 6 months after planting. The period between 6 to 9 months after planting caused a 20.97\% decline in mineral zinc content but there was $16.67 \%$ accumulation at 9 to 12 months after planting. The results of the current study also showed significant $(\mathrm{p} \leq 0.05)$ interaction effect on cassava roots in relation to zinc content (Table 3$)$. Variety Karembo had the highest Zinc $(2.1 \mathrm{mg} / 100 \mathrm{~g}$ dry weight) content at 6 months after planting. Tajirika and Kibanda Meno had their peak zinc content at 12 months that were $1.75 \mathrm{mg} / 100 \mathrm{~g}$ dry weight and $1.94 \mathrm{mg} / 100 \mathrm{~g}$ dry weight respectively. Tajirika's Zinc content at the peak was 1.75 while Kibanda Meno was $1.46 \mathrm{mg} / 100 \mathrm{~g}$ dry weight. These results are within the range that was reported by Charles et al. (2005). His five cassava varieties had zinc content range of between 1.4 and $4.25 \mathrm{mg} / 100 \mathrm{~g}$ dry weight.

Table 3: Variation of vitamin C, Zinc and Iron contents $(\mathrm{mg} / 100 \mathrm{~g}, \mathrm{dwb})$ in three coastal Kenya cassava roots as affected by crop age

\begin{tabular}{llllll}
\hline $\begin{array}{l}\text { Cassava } \\
\text { root } \\
\text { Nutrient }\end{array}$ & $\begin{array}{l}\text { Cassava } \\
\text { Varieties }\end{array}$ & $\begin{array}{l}\text { 3 Months after } \\
\text { planting }\end{array}$ & $\begin{array}{l}\text { 6 Months after } \\
\text { planting }\end{array}$ & $\begin{array}{l}\text { 9onths after } \\
\text { planting }\end{array}$ & $\begin{array}{l}\text { 12 Months after } \\
\text { planting }\end{array}$ \\
\hline \multirow{3}{*}{ Vitamin } & Karembo & $9.36 \pm 0.721^{\mathrm{g}}$ & $64.2 \pm .35^{\mathrm{abc}}$ & $44.3 \pm 0.06^{\mathrm{e}}$ & $32.43 \pm 0.78^{\mathrm{f}}$ \\
$\mathbf{C}$ & Kibanda Meno & $7.39 \pm 0.61^{\mathrm{g}}$ & $66.23 \pm 3.7^{\mathrm{a}}$ & $60.95 \pm 0.96^{\mathrm{bcd}}$ & $46.97 \pm 7.75^{\mathrm{e}}$ \\
Iron & Tajirika & $10.38 \pm 0.08^{\mathrm{g}}$ & $56.61 \pm 0.78^{\mathrm{d}}$ & $69.63 \pm 0.74^{\mathrm{a}}$ & $60.05 \pm 1.0^{\mathrm{cd}}$ \\
& Karembo & $3.63 \pm 0.03^{\mathrm{bed}}$ & $2.14 \pm 1.6^{\mathrm{d}}$ & $2.68 \pm 0.12^{\mathrm{c}}$ & $2.41 \pm 0.18^{\mathrm{d}}$ \\
& Kibanda Meno & $4.26 \pm 0.03^{\mathrm{bc}}$ & $3.03 \pm 1.31^{\mathrm{c}}$ & $7.12 \pm 2.23^{\mathrm{a}}$ & $5.20 \pm 0.08^{\mathrm{b}}$ \\
& Tajirika & $5.33 \pm 0.00$ & $2.87 \pm 1.72^{\mathrm{c}}$ & $2.37 \pm 0.24^{\mathrm{d}}$ & $2.24 \pm 0.18^{\mathrm{d}}$ \\
& & & & & \\
Zinc & Karembo & $0.76 \pm 0.01^{\mathrm{e}}$ & $2.10 \pm 0.28^{\mathrm{a}}$ & $0.84 \pm 0.21^{\mathrm{de}}$ & $1.46 \pm 0.29^{\mathrm{bc}}$ \\
& Kibanda Meno & $0.53 \pm 0.03^{\mathrm{e}}$ & $0.82 \pm 0.05^{\mathrm{d}}$ & $0.67 \pm 0.5^{\mathrm{e}}$ & $1.94 \pm 0.25^{\mathrm{a}}$ \\
& Tajirika & $0.63 \pm 0.05^{\mathrm{e}}$ & $1.24 \pm 0.00^{\mathrm{cd}}$ & $1.50 \pm 0.07^{\mathrm{bc}}$ & $1.75 \pm 0.14^{\mathrm{ab}}$ \\
\hline
\end{tabular}

* Means followed with the same superscript in the same row are not significantly different at $5 \%$ level of significance

\section{Conclusion and Recommendation}

The current study concludes that the crop age has influence on cassava roots' quality but leaving the crop in the field for longer period after planting does not warrant maximum root quality in terms of nutrient levels. At 9 months after planting, several nutrients evaluated in this study are at higher levels but the micronutrients are at higher levels between 3 and 6 months after planting. The study therefore recommends staggered harvesting of cassava roots at different crop ages but at around 9months is best based on dry matter and starch content.

\section{CONFLICT OF INTEREST}

The authors declare that they have no conflict of interest.

\section{AUTHORS' STATEMENT}

The authors of this research confirm that;

a) the data and this research article are original

b) there's no conflicts of interests or any plagiarism issues,

c) the article is not being considered elsewhere

d) the authors are willing to transfer the first publishing right to the publisher if the article is accepted after review

\section{Acknowledgements}

Special appreciation goes to the Director KALRO for giving the first author study leave, NACOSTI for funding 
the research activities, EAPP for funding laboratory reagents and to Dr. H.M. Saha of Pwani University, Kenya for persistent guidance in statistical analysis.

\section{References}

1. AOAC International, (2012). Association of Official Agricultural Chemists 985.29.

2. AOAC International, (2000). Association of Official Agricultural Chemists 985.29

3. AOAC International, (2001). Official Association of Official Agricultural Chemists 925.10

4. AOAC International, (2016). Official Association of Official Agricultural Chemists $17^{\text {th }}$ edition Hydrocyanic acid in Beans 915. 03

5. AOAC International, (2013). Association of Official Agricultural Chemists 967. 21

6. AOAC International, (1995). Association of Official Agricultural Chemists 923.03

7. AOAC International, (2005). Association of Official Agricultural Chemists 979.09

8. AOAC International, (2016). Association of Official Agricultural Chemists 99 (1) 42-52

9. AOAC International, (2005). Association of Official Agricultural Chemists 979.09

10. Aiyelegun, T., Owalarafe, O., Ogunsina, B. Samuel, T, (2017). Inconsistency In the Physico-Chemical Properties of Gari Produced in South-Western Nigeria. Food Processing Engineering. (5), e12526. doi.org/10.1111/ jfpe.12526n

11. Benesi, I.R., L Dixon, M.T., AG, Mahungu N.M. Labuschagne, T.M, (2004) Stability Of Native Starch Quality Parameters, Starch Extraction And Root Dry Matter Of Cassava Genotypes In Different Environments. Journal of the Science of Food and Agriculture.: 84 (11) ; 1381 - 1388

12. Bechoff, A., Tomlins, K., Fliedel, G., Lopez-lavalle, L. B., and Westby, A, (2018). Cassava Traits and EndUser Preference: Relating Traits to Consumer Liking, Sensory Perception, and Genetics. Critical Reviews in Food Science and Nutrition. 58 (4)

13. Burns, A. E., Gleadow, R. M., Zacarias, A. M., Cuambe, C. E., Miller, R. E. and Cavagnaro, T. R, (2012). Variations in the chemical composition of cassava (Manihot esculenta Crantz) leaves and roots as affected by genotypic and environmental variation. Journal of Agriculture Food Chemistry. (19) 4946 - 4956

14. Cardoso, A.P., Mirione, E., Ernesto, M., Massaza, F., Cliff, J., Haque, M.R. and Bradbury, J.H, (2005). Processing Of Cassava Roots to Remove Cyanogens. Journal of Food Composition and Analysis. (18) 451460.

15. Codex food standards, (1989). General Standard for Contaminants and Toxins in Food and Feed. 1 - 1969

16. Charles, A.L., Sriroth, K., Huang, T.C, (2005). Proximate Composition, Mineral Contents, Hydrogen Cyanide, and Phytic Acid of Five Cassava Genotypes. Food Chemistry. (92) 615 - 620

17. Chavez, A. L., Bedoya, J. M., Sánchez, T. S., Iglesias, C., Ceballos, H., and Roca, W. (2000). Iron, Carotene, and Ascorbic Acid in Cassava Roots and Leaves. Journal of Food and Nutrition. 4 - 21

18. Chavez, A. L Sanchez, T., Jaramillo, G., Bedoya, J.M., Echeverry, J., Bolnos, E. ACeballos, H., Iglesias, C. A (2005). Variation of Quality Traits in Cassava Roots Evaluated In Landraces and Improved Clones. Food and Nutrition Bulletin. 21(4)

19. Davidson, G. I., Ene-Obong, H. N., and Chinma, C. E, (2017). Variations in Nutrients Composition of Most Commonly Consumed Cassava (Manihot Esculenta) Mixed Dishes in South-Eastern. Nigeria Journal of Food Quality. 15 - 25

20. Endmemo convertor table, (2017)

21. Enidiok, S.E., Attah, L.E., Otuechere, C.A (2008). Evaluation Of Moisture, Total Cyanide And Fiber Contents Of Garri Produced From Cassava Varieties Obtained From Awassa In Southern Ethiopia. Pakistan Journal of Nutrition. (5) 625 - 629citeseerx.ist.psu.edu/viewdoc/download; accessed on $6^{\text {th }}$ Mar. 2018

22. Eke, J., Achinewhu, S. C., Sanni. L., Barimalaa, I. S., Maziya-Dixon, B., Dixon, A, (2007). Seasonal Variations in the Chemical and Functional Properties of Starches from Local and Improved Cassava Varieties in High Rainfall Region of Nigeria. Journal of Food, Agriculture \& Environment. (3 4); 36 - 42

23. FAO, (2005) Traditional food plants. Food and nutrition paper. (42) $11-19$

24. FAOSTAT, (2013). Statistical Databases. Food and Agriculture Organization of the United Nations. Cassava Production and Consumption.

25. FAO, (2005). Farming Systems in Kenya. Repository Report. (348) 106 - 110

26. FAO, (2005). Overview of Traditional Processing and Utilization of Cassava in Africa. Repository Report.

27. FAO, (1991). Food and Agriculture Organization/World Health Organization.

28. FAO, (2003). Food Energy - Methods of Analysis and Conversion Factors. In FAO Food and Nutrition Paper 77.

29. Gethi, J., Muli, B.M., Saha, H. M, (2009).Rockefeller Funded Project Report on Cassava Varieties Bred for Coastal Kenya. 5 - 35

30. Githunguri, C. M, (1995). Cassava Food Processing and Utilization in Kenya. Horizon Documentation. 415 - 465. http://horizon.documentation.ird.fr/exl; accessed on $16^{\text {th }}$ Jan 2018 
31. Imungi, J. K., Onyango, C. A (1989). Incorporation of Cassava into Some Kenyan Traditional Foods. Journal of Ecology of Food and Nutrition. (2); 125 -29

32. Ifeabunike, O. B., Nwaedozie, J.M., Aghanwa, (2017). Proximate Analysis Hydrogen Cyanide and Some Essential Minerals Content of Sweet Cassava Varieties and Bitter Cassava Variety in Kachia Local Government Area of Kaduna State. 19 (1) $1-12$.

33. KARI, (2009). KARI Annual report. $25-35$.

34. Kalawole, O. F., Akingbala, J.O, (2010). Utilization of Cassava for Food. Journal of Food Reviews International. (1) $51-83$

35. Mouafi, A. S. Djabou., Qin, Yuling., Thaddee, B., Gonzales., P. F., Feifei, A., Carvalho, L.J. C., Ndoumou, O. D., Kaimian, L., Niemenak, N., Songbi, C, (2018). Effects of Calcium and Magnesium Fertilization on Antioxidant Activities during Cassava Postharvest Physiological Deterioration. Journal of Crop Science. (58) $1385-1392$

36. Montagnac, J. A., Davis, R.C., Tanumihardjo, S. A, (2009). Nutritional Value of Cassava for Use as Staple Food. Journal of Comprehensive Reviews in Food Science and Safety. (3) $181-194$

37. Mwamachi, D. M (2005). Baseline survey on cassava production, utilization and marketing carried out in. In KARI Annual Report. 40 - 70

38. Muli, B.M., Saha, H. M., Gethi, J.G (2008). New Cassava Varieties for Farmers in Coast Lowland Kenya. Farmers Pride. 7 September Issue

39. Mishra, A, (2017). Soxhlet Extraction Method- Estimation of Fat in Food. https://discoverfoodtech.com/soxhlet-extraction-method. accessed on 23 Aug 2017

40. Nhassico, D., Muquingue, H., Cliff, J., Cumbana, A., \& Bradbury, J. H, (2008). Rising African CassavaProduction, Diseases Due To High Cyanide Intake And Control Measures. Journal of the Science of Food and Agriculture. (88) 2043 - 2049

41. Omosuli, S.V, (2014). Effects of Processing On the Chemical and Anti-Nutritional Properties of Cassava Roots. Journal of Botanical Sciences. 2320 - 0189

42. Onwuka, G. I and Ogbogu, N. J, (2007). Effect Of Fermentation On The Quality And Pysico Chemical Properties Of Cassava Based Fufu Products Made From Two Cassava Varieties. Journal of Food Technology. (30) $261-264$

43. Richardson, K. V, (2013). Quality Characteristics, Root Yield and Nutrient Composition of Six Cassava (Manihot Esculenta Crantz) Varieties. Gladstone Road Agricultural Centre Crops Research Report. (18) 1 13

44. Rijssen, F. W., Morris,E. J. and Eloff, J. N (2013). Food Safety: Importance Of Composition For Assessing Genetically Modified Cassava (Manihot Esculenta Crantz). Journal of Agriculture and Food Chemistry. (35) $8333-8339$

45. Salvador E. M., Steenkamp, V., and McCrindle, C. M. E (2014). Production, Consumption And Nutritional Value Of Cassava (Manihot Esculenta,Crantz) In Mozambique: An Overview, Journal of Agricultural Biotechnology And Sustainable Development. (3) 29 - 38

46. Salcedo, A., Valle, A. D., Sanchez, B., Ocasio, V., Ortiz, A., Arquez, P., Siritunga, D, (2010). Comparative Evaluation of Physiological Post-Harvest Root Deterioration of 25 Cassava (Manihot Esculenta) Accessions: Visual Vs .Hydroxycoumarins Fluorescent Accumulation Analysis. African Journal of Agricultural Research. (5) 3138 - 3144.

47. Shobha, D., Kumar, H. V. D., Sreeramasetty, T. A., Gowda, K. T. P., \& Shivakumar G. B, (2012). Storage Influence on the Functional, Sensory and Keeping Quality of Quality Protein Maize Flour. Journal of Food Science and Technology. 10

48. Srihawong, W., Kongsil, P., Petchpoung and Sarobol, E, (2015). Effect of Genotype, Age and Soil Moisture on Cyanogenic Glycosides Content and Root Yield in Cassava (Manihot Esculenta Crantz). Journal of Natural Science. (49) $844-855$

49. Topor, V.A., Michelle,R.C., Fuetebella, C., Bacolod, H.J \& Arameta, L.A, (2008). Cyanide Content of the Roots and Leaves of Cassava (Manihot Esculenta Crantz) From Selected Sources in Iloilo. Journal of Natural Science. (13) 25 - 34

50. Ubwa, S. T., Otache, M. A., Igbum, G. O., Shambe, T, (2015). Determination of cyanidcontent in three sweet cassava cultivars in three local government areas of Benue State, Nigeria. Journal of Food and Nutrition Sciences. (6) 1078 - 1085

51. Wekesa, C., Ongugo, P., Ndalilo, L., Amur, A., Mwalewa S and Swiderska, K, (2017). Country Report Smallholder Innovation For Resilience (SIFOR) September Issue

52. Wobeto, C., Corrêa, A. D., De Abreu, C. M. P, Dos Santos C. D., Pereira, H. V, (2007). Anti-Nutrients in the Cassava (Manihot Esculenta Crantz) Leaf Powder at Three Ages of the Plant; American Journal of Food Science and Technology. (27) 108 - 12 